\title{
The NHS deserves better than this dash to market
}

\author{
Fiona Godlee editor, BMJ
}

With apologies to those for whom it holds no interest, I am writing for a second week about England's NHS (doi:10.1136/ bmj.f1850). We are now only days away from the introduction of new NHS regulations. Drafted in February, hastily revised by the government last week because of fierce criticism, and due to be enacted in a few days' time, they are designed to open up the NHS in England to competition by for-profit corporations. The $B M J$ has a reputation for anti-market sentiment when it comes to the provision of healthcare, and views on the new regulations are polarised. So to balance last week's coverage we have commissioned a debate aiming to reflect both sides of the argument and inform readers about what's going on.

Does April 1 mark the beginning of the end of England's NHS? David Hunter says it does, and he invites those who think this is just left wing scaremongering to take a close look at what is happening in other health systems where similar marketisation is underway (doi:10.1136/bmj.f1951). Julian Le Grand, former advisor to Tony Blair during the New Labour healthcare reforms, says the fear of competition is misplaced, especially since "large chunks of the NHS are already private and have been since 1948." (doi:10.1136/bmj.f1975) We should direct our fears towards austerity measures, he says, not the market.

I asked last week whether people understand what is happening. Clare Gerada confirms my view that we don't. In her editorial she says that we are dealing with "a set of regulations that no one understands and that seem to conflict with the previously stated intentions of the government that wrote them." (doi:10. 1136/bmj.f1977). Even someone as engaged and impressive as the chief executive of NHS London, Ruth Carnall, admits to confusion. In a recent tweet quoted by Gerada, Carnall says, "I'm supposed to know what's going on re all of this. I don't." And she's not alone. The House of Lords committee responsible for scrutinising the regulations concluded last week that there is "no common understanding" of the new rules, saying that the Department of Health has given "insufficient time" to set the system up properly and enable thorough scrutiny.

Gerada herself is in no doubt about what the new regulations mean. They allow for "the wholesale dismantling of the NHS and privatisation of the supply, organisation, planning, finance, and distribution of healthcare." Nor does she doubt the consequences. The regulations will leave general practitioners "bearing the brunt of the public's wrath, while much of the health budget is handed over to the for-profit commercial sector, services are closed, and entitlements to universal healthcare are eroded."

The government wants the regulations in place when the National Commissioning Board takes over England's NHS on April 1. But members of the House of Lords may still be able to limit the extent of subsequent privatisation by forcing a debate at the end of April (doi:10.1136/bmj.f1983). If they succeed, this will be a once in a lifetime chance to influence the future of England's NHS, and we must seize it on behalf of present and future generations. 